\title{
INFESTASI EKTOPARAIT PADA IKAN NILA (Oreochromis niloticus) YANG DIPELIHARA DENGAN MENGGUNAKAN SISTEM AKUAPONIK DAN TANPA AKUAPONIK
}

\section{Ectoparasites Infestation on Oreochromis Niloticus Maintained by Using Aquaponic and Non-Aquaponic System}

\author{
Ewing Mahendra Putra ${ }^{1}$, Gunanti Mahasri² dan Luthfiana Aprilianita Sari ${ }^{3}$. \\ ${ }^{1}$ Program Studi Budidaya Perairan, Fakultas Perikanan dan Kelautan, Universitas Airlangga, Surabaya \\ ${ }^{2}$ Departemen Manajemen Kesehatan Ikan dan Budidaya Perairan, Fakultas Perikanan dan Kelautan, Universitas \\ Airlangga, Surabaya \\ *alfan-p-11@fpk.unair.ac.id
}

\begin{abstract}
Abstrak
Penelitian ini bertujuan untuk mengetahui jenis ektoparasit dan perbedaan infestasi ektoparasit pada ikan nila (Oreochromis niloticus) yang dipelihara pada sistem akuaponik dan tanpa akuaponik. Metode penelitian rnenggunakan kuasi eksperimen intact-group comparison dengan terdapat dua perlakuan. Hewan uji menggunakan ikan nila dengan bobot 6-7 g/ekor. Hewan uji dipelihara di akuarium kaca berukuran $40 \mathrm{~cm} \times 30 \mathrm{~cm} x 30 \mathrm{~cm}$ yang diisi air sebanyak 15 liter. Perlakuan yang diberikan berupa pemeliharaan ikan nila dengan menggunakan sistem akuaponik dan pemeliharaan ikan nila tanpa menggunakan sistem akuaponik. Parameter yang diamati adalah jenis ektoparasit dan infestasi ektoparasit pada ikan nila. Jenis parasit yang ditemukan menginfestasi ikan nila (Oreochromis niloticus) pada pemeliharaan dengan menggunakan akuaponik maupun tanpa akuaponik adalah Argulus sp. Terdapat perbedaan yang nyata antara infestasi ektoparasit pada ikan nila (Oreochromis niloticus) yang dipelihara dengan sistem akuaponik dan tanpa akuaponik.
\end{abstract}

Kata kunci: Infestasi, Ikan Nila (Oreochromis niloticus), Ektoparasit dan Akuaponik

Abstract

This study aims to determine the type of ectoparasites and differences in ectoparasitic infestation on tilapia (Oreochromis niloticus) which are maintained on aquaponic and non-aquaponic systems. The research method used quasi experimental intact-group comparison with two treatments. Animals test using tilapia fish with a weight of 6-7 g / fish. Test animals kept in a glass aquarium size $40 \mathrm{~cm} x 30 \mathrm{~cm} x 30 \mathrm{~cm}$ filled with water as much as 15 liters. The treatment provided in the form of tilapia fish maintenance by using the Aquaponic system and without using the system ofaquaponic. The parameters observed were kind of ectoparasite and ectoparasitic infestation on tilapia. The type of parasite found to infest the tilapia on maintenance using aquaponics or without an isaponic is Argulus sp. There is a marked difference between ectoparasite infestation in tilapia which is maintained with aquaponic and non-meaponic systems.

Keywords: Infestation, Tilapia (Oreochromis niloticus), Ectoparasites and Aquaponic

\section{PENDAHULUAN}

Ikan nila (Oreochromis niloticus) merupakan salah satu komoditas perikanan yang memiliki nilai ekonomi yang tinggi. Ikan nila sangat digemari oleh masyarakat Indonesia karena rasa daging yang enak dan memiliki daging yang tebal serta kandungan gizi daging ikan nila yang tinggi. Menurut Rahmi (2012), ikan nila merupakan salah satu komoditas ekspor unggulan yang jumlah permintaannya semakin meningkat.
Permintaan yang semakin meningkat tersebut terbukti dengan meningkatnya jumlah produksi ikan nila dari tahun ke tahun terus meningkat. Berdasarkan data yang di peroleh dari KKP (2017), pada tahun 2013 produksi ikan nila naik sebanyak 914,78 ribu ton, pada tahun 2014 produksi naik menjadi 999,69 ribu ton sedangkan pada tahun 2015 produksi ikan nila mencapai 1084 juta ton. Akuaponik merupakan bio-integrasi dari akuakultur berprinsip resirkulasi dan 
produksi tanaman hidroponik. Akuaponik berperan dalam mengurangi limbah nitrogen sisa pakan yang tidak terkonsumsi dan metabolisme ikan (Hermawan, 2015). Menurut Nugroho dkk. (2012) penggunaan sistem budidaya akuaponik dapat memperbaiki kualitas air media pemeliharaan ikan. Menurut Pudjiastuti (2015) sumber air dari perairan umum dapat meningkatkan reksiko terbawanya patogen ke dalam kolam budidaya dan dapat menyebabkan fluktuasi suhu air yang terlalu cepat, sehingga dapat mengakibatkan ikan menjadi stress dan mudah terserang patogen. Keberadaan parasit oportunistis yaitu organisme yang dapat menjadi parasit jika lingkungannya mendukung (Fransisca dkk., 2015), dapat menjadi salah satu penyebab terinfestasinya ikan dalam kolam budidaya jika lingkungan perairan tidak terjaga.

Kendala dalam budidaya ikan khususnya ikan nila yang dapat menghambat produksi ikan nila yaitu penyakit. Penyakit ikan dalam budidaya ikan merupakan salah satu masalah yang sangat sering dijumpai. Menurut Lestari (2015), Penyakit dapat disebabkan oleh agen infeksius seperti parasit, virus dan bakteri. Penyakit pada ikan pada umumnya timbul akibat tidak seimbangnya tiga faktor. Faktor-faktor tersebut adalah inang, patogen dan lingkungan (Novriadi $d k k .$, 2014). Parasit merupakan organisme yang hidupnya dapat merugikan organisme lain (inangnya) dan dapat menyebabkan penyakit. Parasit merugikan organisme lain karena parasit tersebut dapat mengambil nutrien dari inangnya sehingga dapat mengakibatkan kematian. Infeksi parasit yang menyerang ikan air tawar biasanya berhubungan dengan lingkungan yang kurang baik, suhu dan salinitas yang tinggi sering menjadi lemahnya daya tahan tubuh pada ikan, sehingga ikan menjadi lebih mudah stress dan terinfeksi oleh penyakit (Karno, 2007). Ektoparasit pada umumnya dapat muncul dikarenakan beberapa faktor. Kualitas air yang buruk, pemberian pakan ikan yang berlebih dan perubahan iklim merupakan faktor penyebab munculnya parasit (Pudjiastuti, 2015).

Penggunaan sistem budidaya akuaponik yang dapat memperbaiki kualitas air yang buruk dan dapat memanfaatkan limbah pakan, merupakan salah satu jalan keluar bagi produsen ikan nila untuk mempersempit kemungkinan tumbuhnya ektoparasit. Menurut Somerville et al. (2014), dengan mempertahankan kualitas air yang baik, ikan yang dibudidayakan dapat lebih tahan terhadap infestasi parasit dan penyakit lainnya dengan memanfaatkan imun tubuhnya. Oleh sebab itu penelitian ini bertujuan untuk mengatahui infestasi ektoparasit pada ikan nila yang dipelihara pada sistem akuaponik dan tanpa akuaponik.

\section{METODOLOGI \\ Waktu dan Tempat}

Penelitian ini dilaksanakan pada bulan Juni 2017 sampai Januari 2018 di Fakultas Perikanan dan Kelautan, Universitas Airlangga. Pemeriksaan ektoparasit akan dilaksanakan di Laboratorium Fakultas Perikanan dan Kelautan, Universitas Airlangga, Surabaya.

\section{Materi Penelitian}

Peralatan Penelitian

Alat-alat yang digunakan dalam penelitian ini antara lain mikroskop, objek glass, pisau bedah, kamera, 10 akuarium ukuran 30x30x40 cm, bak persiapan, DO meter, $\mathrm{pH}$ indikator, termometer, talang air, arang, kerikil, aerator, selang aerator, batu aerator, pompa air dan pipa saluran air.

\section{Bahan Penelitian}

Bahan-bahan yang digunakan dalam penelitian ini adalah benih ikan nila (Oreochromis niloticus) ukuran 7-8 cm, air dari perairan umum, kangkung air, arang, klorin dan pakan ikan komersial.

\section{Metode Penelitian}

Metode yang digunakan dalam penelitian ini merupakan metode eksperimental dengan menggunakan desain eksperimen yaitu kuasi eksperimen IntactGroup Comparison. Desain penelitian Intact-Group Comparison hanya memiliki satu kelompok yang digunakan penelitian, tetapi dibagi menjadi dua yaitu setengah 
kelompok untuk eksperimen (diberi perlakuan) dan setengah kelompok lainnya untuk kelompok kontrol (tanpa perlakuan) (Sugiyono, 2010).

\section{Prosedur Kerja \\ Persiapan Alat dan Bahan}

Semua peralatan yang akan digunakan dalam penelitian disterilkan terlebih dahulu. Sterilisasi adalah suatu proses untuk membunuh semua jasad renik yang ada, sehingga jika ditumbuhkan di dalam suatu medium tidak ada lagi jasad renik yang dapat berkembang biak. Sterilisasi alat dan bahan dilakukan menggunakan larutan klorin 1,5 ppm dan direndamkan selama 24 jam (Arief $d k k ., 2014$ ). Alat-alat yang disterilisasi berupa akuarium, selang aerasi, batu aerasi, pipa saluran air dan talang air.

\section{Pembuatan Rangkaian Budidaya}

Media tanam yang digunakan berupa arang dan tanaman yang digunakan adalah kangkung air. Media tanam berupa arang memiliki ketebalan $5 \mathrm{~cm}$ diatas permukaan tempat pemeliharaan tanaman. Kangkung air yang telah disemai hingga memiliki panjang 5-8 cm ditanam dengan jarak $5 \mathrm{~cm}$ per kangkung. Desain pada akuarium tanpa akuaponik hanya memanfaatkan aerator yang berfungsi sebagai penghasil oksigen dalam air. Akuarium tanpa akuaponik tidak menggunakan sistem resirkulasi air.

\section{Persiapan Benih Ikan Nila (Oreochromis niloticus)}

Benih ikan nila yang digunakan pada penelitian ini berasal dari UPT PBAT Umbulan, Pasuruan. Benih ikan nila dibeli sebanyak 400 ekor dengan ukuran 7-8 cm. Benih ikan nila yang dibeli dipastikan sehat dengan cara memeriksa 10 ekor ikan nila. Benih ikan nila setelah sampai pada lokasi penelitian diaklimatisasi terlebih dahulu dalam bak persiapan. Benih ikan nila sebelum digunakan dalam penelitian dipelihara terlebih dahulu selama 1 hari.

\section{Pemeliharaan}

Benih ikan nila dengan berat antara 6-7 g/ekor dipelihara pada akuarium dengan kepadatan 10 ekor/akuarium ukuran 30x30x40 cm dengan 15 liter air. Penelitian ini bertujuan untuk mengetahui perbandingan prevalensi ektoparasit pada ikan nila yang dipelihara dengan akuaponik dan tanpa akuaponik, sehingga pemeliharaan ikan nila selama 4 minggu (28 Hari) dirasa cukup untuk dapat memperoleh hasil prevalensi ektoparasit yang menyerang ikan nila pada akuarium dengan perlakuan akuaponik maupun tanpa perlakuan akuaponik. Ikan nila yang dipelihara diberi pakan komersil 3 kali sehari (pagi, siang, sore) dengan metode pemberian pakan ad libitum.

\section{Pengamatan Parameter Penelitian}

Pemeriksaan infestasi ektoparasit dilakukan pada akhir penelitian. Sampel ikan dibawa untuk diperiksa di Laboratorium Fakultas Perikanan dan Kelautan, Universitas Airlangga. Pemeriksaan dilakukan untuk menentukan jumlah ikan nila yang positif $(+)$ terinfestasi ektoparasit dan jumlah ikan nila yang negatif (-) terinfestasi ektoparasit pada setiap perlakuan. Jenis ektoparasit diperiksa menggunakan metode scrapping pada permukaan tubuh ikan dan insang kemudian diamati di bawah mikroskop dengan perbesaran 40x dan 100x. Pemeriksaan jenis ektoparasit dilakukan pada akhir penelitian.

Kelangsungan hidup ikan merupakan perbandingan jumlah ikan yang hidup di awal dan akhir penelitian. Rumus yang digunakan untuk menghitung kelangsungan hidup ikan adalah sebagai berikut (Effendie, 1997):

$$
\mathrm{SR}=\frac{N o-N t}{N o} \times 100 \%
$$

Keterangan : No = Jumlah ikan pada awal penelitian

$\mathrm{Nt}=$ Jumlah ikan pada akhir penelitian

$\mathrm{SR}=$ Tingkat Mortalitas 
Parameter kualitas air yang diperiksa pada penelitian ini adalah $\mathrm{DO}, \mathrm{pH}$, suhu dan kadar amonia. Pemeriksaan kualitas air dilakukan setiap hari senin, rabu dan jumat.

\section{Analisis Data}

Data yang diperoleh dalam penelitian ini berdasarkan parameter utama infestasi ektoparasit diuji dengan menggunakan uji Mann-Whitney. Jenis ektoparasit yang diperoleh dianalisis secara deskriptif. Data dicantumkan dalam bentuk tabel dan gambar.

\section{HASIL DAN PEMBAHASAN \\ Infestasi Ektoparasit Pada Ikan Nila (Oreochromis Niloticus)}

Hasil Infestasi ektoparasit yang didapatkan dari pemeliharaan ikan nila dengan sistem akuaponik dan tanpa akuaponik dapat dilihat pada tabel berikut ini.

Tabel 1. Hasil Pemeriksaan Infestasi Ektoparasit pada Ikan Nila

\begin{tabular}{cccc}
\hline Perlakuan & Jumlah Ikan yang Diperiksa & Positif (\%) & Negatif (\%) \\
\hline Tanpa Akuaponik & 50 & 18 & 82 \\
Akuaponik & 50 & 4 & 96 \\
\hline
\end{tabular}

Uji Mann-Whitney pada infestasi ektoparasit antara ikan nila yang dipelihara dengan sistem akuaponik dan tanpa akuaponik menunjukkan hasil berbeda nyata $(\mathrm{P}<0,05)$ yaitu 0,021 . Persentase ikan nila yang terinfestasi ektoparasit yang dipelihara dengan tanpa akuaponik didapatkan hasil $18 \%$ populasi ikan nila terinfestasi oleh ektoparasit, sedangkan ikan nila yang dipelihara dengan akuaponik didapatkan hasil 4\% populasi ikan nila terinfestasi oleh ektoparasit.

\section{Jenis Ektoparasit Pada Ikan Nila (Oreochromis Niloticus)}

Jenis ektoparasit yang menginfestasi ikan nila yang dipelihara dengan sistem akuaponik dan tanpa akuaponik adalah Argulus sp.. Tidak terdapat perbedaan jenis parasit yang menginfestasi ikan nila. Ciri-ciri morfologi ektoparasit Argulus yang ditemukan pada ikan nila adalah bentuk tubuh oval, memiliki 4 pasang kaki yang digunakan untuk berenang, memiliki alat penghisap yang digunakan untuk menghisap darah pada ikan, hampir seluruh bagian tubuhnya terlindungi oleh karapas, Argulus sp. yang ditemukan pada permukaan ikan nila yang dipelihara dengan perlakuan tanpa akuaponik memi- liki ukuran 0,2-0,5 cm, sedangkan pada perlakuan akuaponik memiliki ukuran 0,30,4 cm (Gambar 1).

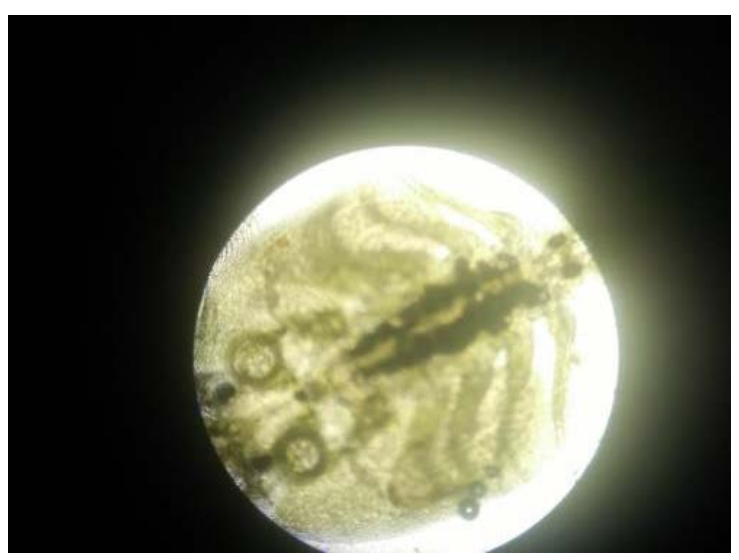

Gambar 1. Argulus sp. (Perbearan 40x)

Ciri-ciri morfologi tersebut sesuai dengan pendapat Poly (2000), yaitu Argulus memiliki tubuh yang tipis, memiliki ukuran tubuh 5-10 mm, memiliki 4 pasang kaki renang, memiliki karapas pada sebagian dari Thorax, pada bagian maxilia terdapat organ yang dapat digunakan untuk menyerang host. Menurut Kabata (1985), Argulus memiliki tiga bagian tubuh yaitu chepalothorax, thorax dan abdomen. Pada chepalothorax terdapat dua pasang maxilla, dimana maxilla pertama termodifikasi menjadi alat penghisap untuk menghisap 
ikan inangnya. Pada thorax terdapat 3 segmen yang pada setiap segmennya terdapat sepasang kaki untuk berenang, sedangkan sepasang kaki ke empat terdapat diantara abdomen dan thorax.
Argulus sp. yang menginfestasi ikan nila pada perlakuan akuaponik dan tanpa akuaponik dapat dilihat pada tabel berikut ini.

Tabel 2. Hasil Pemeriksaan Ektoparasit

\begin{tabular}{cccc}
\hline Perlakuan & Jenis Ektoparasit & Jumlah Ektoparasit & Ukuran Parasit (cm) \\
\hline Tanpa Akuaponik & Argulus sp. & 9 & $0,2-0,5$ \\
Akuaponik & Argulus sp. & 9 & $0,3-0,4$ \\
\hline
\end{tabular}

\section{Survival Rate (kelulushidupan)}

Perhitungan kelulushidupan antara ikan nila yang dipelihara dengan perlakuan tanpa akuaponik dan tanpa akuaponik dapat dilihat pada Tabel 5.3 berikut ini.

Tabel 3. Hasil Kelulushidupan Ikan Nila

\begin{tabular}{cc}
\hline Perlakuan & $\begin{array}{c}\text { Kelulushidupan Ikan Nila } \\
(\%)\end{array}$ \\
\hline Tanpa Akuaponik & 82,00 \\
Akuaponik & 88,00 \\
\hline
\end{tabular}

Ikan nila yang dipelihara selama satu bulan dengan perlakuan tanpa akuaponik memiliki tingkat kelulushidupan sebesar 82\%, sedangkan ikan nila yang dipelihara dengan akuaponik memiliki tingkat kelulushidupan 88\%.

\section{Kualitas Air}

Pengukuran parameter kualitas air meliputi data suhu, $\mathrm{pH}$, Ammonia, dan oksigen terlarut (DO), hasil dapat dilihat pada Tabel 4. berikut ini.

Tabel 4. Hasil Pemeriksaan Kualitas Air

\begin{tabular}{ccccc}
\hline Perlakuan & Suhu $\left({ }^{\circ} \mathrm{C}\right)$ & $\mathrm{pH}$ & Ammonia $(\mathrm{mg} / \mathrm{l})$ & $\mathrm{DO}(\mathrm{mg} / \mathrm{l})$ \\
\hline Tanpa Akuaponik & $26-30$ & $7,2-7,9$ & 0,27 & $3,0-4,0$ \\
Akuaponik & $27-30$ & $7,8-8,5$ & 0,003 & $3,5-5,0$ \\
$\quad$ Normal & & & & $>5$ \\
$\begin{array}{c}\text { (Tatangindatu dkk., } \\
\text { 2013) }\end{array}$ & $28-32$ & $6,8-8,5$ & $<0,02$ & \\
\hline
\end{tabular}

Hasil pemerikasaan kualitas air yang di periksa sebanyak seminggu tiga kali pengecekan selama satu bulan dengan mendapatkan hasil suhu pada kedua perlakuan sedikit lebih rendah dibandingkan dengan suhu normal, sedangkan $\mathrm{pH}$ air pada kedua perlakuan normal dengan nilai pH pada perlakuan tanpa akuaponik sebesar 7,2-7,9 dan dengan akuaponik 7,88,5. DO pada perlakuan tanpa akuaponik mendapatkan hasil lebih rendah jika dibandingkan dengan perlakuan menggunakan akuaponik. Hasil pemeriksaan DO pada perlakuan akuaponik berkisar antara 3,55,0 mg/l sedangkan tanpa akuaponik 3,04,0 mg/l, perlakuan tanpa akuaponik memiliki DO dibawah normal. Ammonia pada penelitian ini di periksa seminggu sekali selama satu bulan dan mendapatkan hasil ammonia tertinggi pada perlakuan tanpa akuaponi sebesar 0,27 mg/l, sedangkan pada perlakuan akuaponik kadar ammonia tertinggi hanya sebesar 0,003 $\mathrm{mg} / \mathrm{l}$. 


\section{Pembahasan}

Penelitian ini menggunakan ikan nila (Oreochromis niloticus) yang berasal dari UPT PBAT Umbulan, Pasuruan. Ikan nila dalam penelitian ini diberikan dua perlakuan yang berbeda, yaitu perlakuan pemeliharaan ikan nila pada sistem akuaponik dan pemeliharaan ikan nila tanpa menggunakan sistem akuaponik. Jumlah ikan nila yang dipelihara pada masingmasing perlakuan berjumlah 50 ekor ikan. Media air pemeliharaan didapatkan dari kolam induk ikan nila yang berada di UPT PBAT umbulan. Jenis ektoparasit yang ditemukan dalam penelitian ini adalah Argulus sp.. Keberadaan ektoparasit Argulus sp. dalam penelitian ini, diduga disebabkan karena terbawanya larva parasit pada saat pengambilan air di kolam induk ikan nila yang berada di UPT PBAT Umbulan, pasuruan. Beberapa hari sebelum diambilnya air untuk penelitian ini, petugas UPT PBAT Umbulan menemukan sejumlah infestasi Argulus pada induk ikan nila (UPT PBAT Umbulan, 2017). Menurut Daelani (2001), parasit Argulus dapat berenang bebas dan berpindah tempat dari ikan ke ikan lainnya. Sehingga kemungkinan terbawanya parasit Argulus dalam penenilian ini disebabkan karena terbawanya parasit pada saat pengambilan air media pemeliharaan.

Parasit Argulus sp. merupakan ektoparasit yang sering menginfestasi ikan air tawar khususnya ikan nila. Ikan air tawar seperti ikan nila sangat mudah terserang oleh parasit seperti Argulus (Ode, 2012). Parasit ini ditemukan pada bagian permukaan tubuh ikan nila, khususnya pada bagian sirip punggung dan sirip ekor ikan nila. Menurut Jasminandar (2011), parasit Argulus biasanya menginfestasi ikan pada bagian kulit atau sirip dan dapat menimbulkan lubang kecil yang akhirnya dapat menimbulkan infeksi yang disebabkan bakteri dan jamur. Ukuran Argulus sp. yang didapatkan pada penelitian ini memiliki panjang 0,2-0,5 cm.
Parasit ini dapat dilihat dengan mata telanjang tanpa bantuan mikroskop.

Hasil statistik dari perbandingan infestasi ektoparasit pada ikan nila menunjukkan perbedaan yang nyata $(\mathrm{P}<0,05)$ yaitu 0,021 . Hasil pemeliharaan dengan menggunakan sistem akuaponik lebih baik jika dibandingkan dengan pemeliharaan tanpa akuaponik. Perbedaan infestasi ektoparasit pada perlakuan pemeliharaan dengan akuaponik dan tanpa akuaponik dapat disebabkan oleh beberapa faktor. Menurut Sarjito $d k k$. (2013), faktor yang dapat menumbuhkan penyakit dalam pemeliharaan ikan adalah faktor lingkungan, faktor inang dan faktor patogen. Beberapa faktor yang berperan terhadap serangan penyakit pada ikan adalah kepadatan ikan yang dibudidaya dan stres. Penyakit pada ikan disebabkan oleh faktor biotik dan abiotik yaitu faktor fisik dan kimiawi air dan berbagai organisme patogen.

Kualitas air merupakan salah satu faktor lingkungan yang perlu untuk diperhatikan dalam berbudidaya. Ektoparasit dapat mudah sekali tumbuh jika kualitas air budidaya ikan buruk (Winaruddin $d k k$., 2015). Perbedaan kualitas yang paling mencolok dalam penelitian ini adalah kadar amonia dalam air pada kedua perlakuan. Kadar amonia pada perlakuan pemeliharaan ikan nila dengan menggunakan sistem akuaponik mendapatkan hasil 0-0,003 mg/L, sedangkan kadar amonia pada perlakuan pemeliharaan ikan nila tanpa sistem akuaponik mendapatkan hasil 0,003-0,27 mg/L. Menurut Tatangindatu dkk. (2013), kadar maksimum amonia dalam air yang baik dalam budidaya ikan adalah lebih kecil dari 0,02 mg/L dan kadar oksigen terlarut dalam air yang baik dalam budidaya lebih besar dari $5 \mathrm{mg} / \mathrm{L}$. Buruknya kualitas air pada perlakuan tanpa akuaponik (amonia lebih dari 0,02 dan DO kurang dari $5 \mathrm{mg} / \mathrm{L}$ ), dapat menstimulasi tumbuhnya ektoparasit pada ikan nila dan mengakibatkan ikan nila menjadi stress. Ikan nila dengan kondisi stress dapat melemahkan kondisi tubuh 
ikan sehingga ikan nila dengan kondisi tubuh lemah dapat dengan mudah terserang oleh ektoparasit (Putri $d k k$., 2016).

Taraf kelulus hidupan (SR) ikan nila yang dipelihara dengan tanpa akuaponik sedikit lebih rendah yaitu $82 \%$, sedangkan taraf kelulus hidupan ikan nila yang dipelihara dengan menggunakan sistem akuaponik mencapai 88\%. Kelulus hidupan pada kedua perlakuan dalam penelitian ini termasuk baik, sesuai dengan pendapat Djunaedi $d k k$. (2016), yang menyatakan bahwa budidaya ikan yang baik memiliki tingkat kehidupan diatas 80\% (>80\%). Hasil kelulus hidupan pada kedua perlakuan tidak berbeda jauh karena infestasi dari parasit Argulus tidak mengakibatkan kematian pada ikan, akan tetapi dapat mengakibatkan infeksi sekunder seperti jamur ataupun bakteri, serta pengelolaan budidaya ikan yang baik selama penelitian berlangsung. Hasil kelulushidupan dapat berbeda jika penelitian berlangsung selama tiga bulan, dimana siklus hidup argulus telah sempurna. Menurut Grandiosa (2012), infestasi parasit Argulus walaupun tidak mengakibatkan kematian, luka yang dihasilkan oleh infestasi Argulus dapat menyebabkan berbagai pathogen lainnya seperti jamur, bakteri atau virus dapat menyerang ikan nila yang dipelihara dan menyebabkan kematian yang banyak. Secara keseluruhan penggunaan akuaponik sangat membantu dalam budidaya ikan nila khususnya pada bagian perbaikan kualitas air ammonia dan kadar oksigen dalam air. Kondisi lingkungan pada pemeliharaan dengan menggunakan akuaponik dapat membantu mencegah tumbuhnya pathogen khususnya parasit yang merugikan bagi ikan nila.

\section{KESIMPULAN DAN SARAN Kesimpulan}

Jenis parasit yang ditemukan menginfestasi ikan nila (Oreochromis niloticus) pada pemeliharaan dengan menggunakan akuaponik maupun tanpa akuaponik adalah Argulus sp. Terdapat perbedaan yang nyata antara infestasi ektoparasit pada ikan nila (Oreochromis niloticus) yang dipelihara dengan sistem akuaponik dan tanpa akuaponik.

\section{Saran}

Saran dari penelitian ini diharapkan dilakukan pengamatan lebih lanjut mengenai infestasi ektoparasit pada ikan yang dipelihara menggunakan sistem akuaponik dengan menggunakan ikan dan sumber air yang berbeda.

\section{DAFTAR PUSTAKA}

Arief, M., N. Fitriani dan S. Subekti. 2014. Pengaruh Pemberian Probiotik Berbeda pada Pakan Komersial Terhadap Pertumbuhan dan Efisiensi Pakan Ikan Lele Sangkuriang (Clarias sp.). Jurnal Ilmiah Perikanan dan Kelautan. 6(1): 49-53.

Daelani. 2001. Menanggulangi Hama dan Penyakit Ikan. Solo : CV. Aneka

Djunaedi, A.,R. Hartati, R. Pribadi, S. Redjeki, R. W. Astuti dan B. Septiarani. 2016. Pertumbuhan ikan Nila Larasati (Oreochromis niloticus) di Tambak dengan Pemberian Ransum Pakan dan Padat Penebaran yang Berbeda. Jurnal Kelautan Tropis. 19(2):131-142.

Effendie, M. I., 1997. Biologi Perikanan. Yogyakarta: Yayasan Pustaka Nusatama.

Fransisca, R., A. D. Apriliani, F. A. Mutiksa, S. Izati dan R. K. Utami. 2015. Hubungan Infeksi Parasit Usus dengan Pengetahuan Perilaku Hidup Bersih Sehat pada Anak SD Bekasi. E-Journal Kedokteran Indonesia. 3(1): 16-20.

Grandiosa, R. 2012. Parasit dan Penyakit Ikan arthropoda. http://blogs.unpad.ac.id/roffigrandi osa/files/2012/04/Parasit-Golongan Arthropoda - Autosaved.pdf. Diakses pada 10 Desember 2017.

Hermawan, D., 2015. Aplikasi Teknologi Aquaponik pada Sistem Pemeliharaan Udang Vaname (Litopenaeus Vannamei) Bersalinitas Rendah 
dengan Tanaman Selada pada Padat Tebar Berbeda. Jurnal Ilmu Pertanian dan Perikanan. 4(1): 7985.

Jasminandar, Y. 2011. Prevalensi Parasit dan Penyakit Ikan Air Tawar yang Dibudidayakan di Kabupaten Kupang. Jurnal Ilmu-ilmu Hayati dan Fisik. 1(4): 13-16.

Kabata, Z., 1985. Parasites and Disease of Fish Cultured in The Tropics. Philadelphia: International Development Resreach Council.

Karno, H., 2007. Identifikasi Protozoa Parasitik pada Kulit, Insang dan Usus Ikan Mas (Cyprinus Carpio) dan Ikan Nila (Oreochromis sp.) di Pasar Empang Bogor. Skripsi. Fakultas Kedokteran Hewan. Institut Pertanian Bogor. Bogor. Lestari, W. 2015. Identifikasi Ektoparasit Ikan Nila Pada Kolam IPAL. Skripsi. Universitas Islam Negeri Sunan Kalijaga. Yogyakarta.

Novriadi, R., S. Agustatik, Hendrianto, R. Pramuanggit dan A. H. Wibowo., 2014. Penyakit Infeksi pada Budidaya Ikan Laut di Indonesia. Balai Perikanan Budidaya Laut Batam. Batam. ISBN:978-602-70003-1-5.

Nugroho, A., L.T. Pambudi, D. Chilmawati dan A. H. C. Haditomo. 2012. Aplikasi Teknologi Aquaponic pada Budidaya Ikan Air Tawar untuk Optimalisasi Kapasitas Produksi. Jurnal Saintek Perikanan.8(1): 46-51.

Ode, I. 2012. Argulus Ektoparasit pada Ikan. BIMAFIKA. 4(1): 413-419.

Poly, W. J., 2000. Zoology-Graduated Students. Southern Illinois University at Carbondale. USA.

Pudjiastuti, N., 2015. Identifikasi dan Prevalensi Ektoparasit pada Ikan Konsumsi di Balai Benih Ikan Siwarak. Skripsi.Jurusan Biologi FMIPA. Universitas Negeri Semarang. Semarang
Putri, S. M., A. H. Haditomo dan Desrina. 2016. Infestasi Monogenea Pada Ikan Konsumsi Air Tawar Di Kolam Budidaya Desa Ngrajek Magelang. Journal of Aquaculture Management and Technology. 5(1): 162-170.

Rahmi, 2012. Identifikasi Ektoparasit pada Ikan Nila (Oreochromis Niloticus) yang Dibudidayakan pada Tambak Kabupaten Maros. Jurnal Ilmu Perikanan. 1(1): 19-23.

Sarjito, S.B. Prayitno dan A.H.C. Haditomo., 2013. Buku Pengantar Parasit dan Penyakit Ikan. Semarang: UPT Undip Press.

Somerville, C., M. Cohen, E. Pantanella, A. Stankus and A. Lovatelli. 2014. Small Scale Aquaponic Food Production. Rome: FAO.

Sugiyono., 2010. Metode Penelitian Kuantitatif Kualitatif \& RND. Bandung: Alfabeta.

Tatangindatu, F., O. Kalesaran dan R. Rompas., 2013. Studi Parameter Fisika Kimia Air pada Areal Budidaya Ikan di Danau Tondano Desa Paleloan Kabupaten Minahasa. Jurnal Budidaya Perairan. 1(2): 8-19.

Winaruddin., R. dan K. Razi., 2015. Infestasi Ektoparasit pada Ikan Lele Dumbo (Clarias Gariepinus) yang dibudidaya di Desa Tumpok Teungoh Kecamatan Banda Sakti Kota Lhokseumawe. Jurnal Edukasi dan Sains Biologi. 4(2): 14-17. 